DOI https://doi.org/10.18551/rjoas.2017-01.23

\title{
RECONCILIATION OF HIGH-TECH AND HIGH-TOUCH FOR SME INNOVATION PERFORMANCE IN INDONESIA
}

\author{
Riduan \\ Department of Management, STIE Muhammadiyah Kalianda, Indonesia \\ E-mail: riduanmob@yahoo.com
}

\begin{abstract}
The euphoria of technology in the Internet of Things (IOT) era is not only more advantageous but also provides double-edged sword effect for high-tech SMEs. In general, high-tech SMEs have a dependence on technology and neglect high touch aspect capacity to build relationships with human resources. Ironically, it is otherwise allegedly in an action as it is assumed to cause innovation imbalance where the product of SME innovation is high-tech but low-touch. Given its importance, this study aims to examine the importance of reconciliation between high-tech and high-touch as entrepreneurial orientation, organizational characteristics and environmental characteristics and their impacts on the innovation performance. The sample of this study consisted of 102 leaders of high-tech SMEs in East Java Province. Method of Data Analysis used in this study was Generalized Structured Component Analysis (CGCA). The results of this study indicate that the reconciliation between high-tech and high-touch aspects of SMEs in term of entrepreneurial orientation, organizational characteristics and environmental characteristics is an important catalyst for the creation of innovation performance. Several recommendations were developed in response to these findings.
\end{abstract}

\section{KEY WORDS}

Entrepreneurial orientation, organizational characteristics, environmental characteristics, innovation performance, SMEs, high-tech, high-touch, Indonesia.

Over the past few years, a new paradigm called Internet of Things (IOT) has become the buzzwords in academic field and industry. IOT is an image in which the virtual world via internet extends connection to every-day-life objects in the real world (Raiwan, 2013; Palma et al., 2014; Samani et al., 2015). The physical objects are transformed into a smart object which allows interoperability between human-to-human, human-to-things and even things-tothings. Products in the IOT era cover various areas such as wearable devices, home automation, e-government and smart city.

Of course, the IOT is a ground zero for a new phase of global transformation. Propelled by technological innovation, IOT generate significant economic opportunities and establish new industries. According to the research results of Bappenas, BPS, UNDP (2001) in the Technological Achievement Index, Indonesia ranks 56th out of 67 countries. Therefore, Indonesia should continue to innovate and produce a wide range of smart products so that in the future, Indonesia is expected to have competitiveness and comparativeness with other countries.

As the development of Internet in Indonesia which becomes cheaper and easier, more and more people use the Internet for various purposes, one of them is for entrepreneurship (Reuber and Fischer, 2011; Berisha-Shaqiri, 2015). Now, many SME entrepreneurs run high tech, tech-savvy, creative, innovative and dynamic businesses (Okorie et al., 2014, SerokaStolka and Tomski, 2015, Liu, 2016).

SMEs in Indonesia are considered to be responsive to the opportunities to create and participate in the IOT era. It is characterized by the development of technopreneur and startup companies such as the developers of software, games, marketplace etc. In addition, the emergence of various development programs of high-tech innovation system of SMEs such as incubation, accelerator, mentorship and tech start-up ecosystem builder. 
Various studies have shown that high-tech touch is able to encourage the performance of innovation in SMEs (Gunawan, 2015; Ndesaulwa 2016; Rehman, 2016). However, the euphoria of assisted technology is not only beneficial but also gives a double-edged sword for high-tech SMEs. In general, high-tech SMEs have a dependence on technology and neglect high-touch aspect capacity to build relationships with human resources.

Ironically, it is otherwise allegedly in an action will lead to SMEs product imbalance, other than high-tech but low-tech. In the future, it will become a setback for SMEs as Saad and Mazarol (2010), Mura and Rosza (2013) and Halim et al (2014) have suggested that high-touch weaknesses of SMEs which include ethics, leadership, human resources management, can cause a negative impact on the innovation performance of SMEs.

Given its importance, this study aims to investigate such high-touch practices of entrepreneurial orientation, organizational characteristics and environmental characteristics that are implemented and the effect on the innovation performance of high-tech SMEs in East Java, Indonesia. This research is expected to give policy consideration and understanding on the application of high-tech elements of SMEs without neglecting high touch elements in order to create sustainable innovation performance.

Furthermore, research on the balance of high-tech and high-touch of enterprises especially SMEs are still rare and offer ample opportunities for academics to explore further. To the state of researcher's mind, research on the balance of high-tech and high-touch is limited to companies such as the research findings of Anderson (1995) on higher education service, Angehr (1998) on the company's website, Rosen (2011) on the pharmaceutical company, Ferrel and Ferrell (2012) regarding the use of social media in company marketing.

It has never been found research on the balance of high-tech and high-touch on SMEs in both developed and developing countries. Previous research in different sectors indicates that there are several factors that can affect business innovation performance as entrepreneurial orientation (Lumpkin and Dess, 2001; Madhoushi, 2011), organizational characteristics (Prajogo and Ahmed, 2006; Katila, 2002 and Katila and Ahuja, 2002) and environmental characteristics (Prajogo and Sohal, 2001, Frishamman and Horte, 2005; Hung, 2007).

For the high-tech SME sector in developing country like Indonesia, this still needs further verification and research. Therefore, this study should fill the gap on the importance of high-touch which consists of entrepreneurial orientation, organizational characteristics and environmental characteristics in improving innovation performance of high-tech SMEs in IOT era.

\section{LITERATURE REVIEW}

The idea of «high-technology» or "high-tech» has several meanings. However, the term «high-tech» is generally associated with something «new» and «advanced». "Hightech» is often associated with the emergence and use of new technologies (Grønhaug and Möller, 2005). On the contrary, the term «high-touch» can be interpreted by dealing with or interacting with people rather than dealing with computers or high-tech (Naisbitt, 1982). In addition, high-touch means having a strong awareness of the complexity of human beings, which is having empathy. Some researchers believe that both aspects should be reconciled, balanced and integrated in offering products or services of an enterprise; there is no exception for SMEs. In fact, the two aspects seem not in line. This study attempted to examine the extent to which the role of high technology which is represented by entrepreneurial orientation, organizational characteristics and environmental characteristics and the effects on innovation performance in high-touch SMEs .

Covin and Lumpkin (2011) argues that entrepreneurial orientation is the process by which individuals within a founded society pursue entrepreneurial opportunities to innovate regardless the level and nature of the resources currently available. Entrepreneurial orientation is an attempt to extend the competitive advantage of organizations. In addition, Moreno and Casillas (2008) argue that entrepreneurial orientation is organization decisionmaking with a tendency to support entrepreneurial activities. Entrepreneurial orientation is a 
way to act the entrepreneurial spirit within an organization. In addition, organizational characteristics is structure and infrastructure equipment in organizations which is related to the preparation of the implementation of a management strategy $(\mathrm{Li}, 2002)$. Furthermore, the environmental characteristics are environmental factors that affect the level of implementation of a business strategy where there are three main factors which strongly influence including uncertainties in the business environment, competitive pressure to implement business and business college readiness to collaborate ( $\mathrm{Li}, 2002)$. Finally, the concept of innovation performance refers to the organization's overall ability to introduce new innovative products into the market, open new markets by merging the strategic orientation to behavior and innovation process.

This study proposes three hypotheses based on earlier research which became the theoretical and empirical basis. Lumpkin and Dess (2001), in an entrepreneurial orientation model have been developed, reveal that the company's focus consisting of freedom, innovation, risk, proactive, competitive aggressiveness influence the company's performance after creating innovation on company and organizational factors as moderator variable. results of research conducted by Madhoushi (2011) to 164 SMEs in Iran using LISREL data analysis method found that managerial knowledge and entrepreneurial orientation have significant effect on the innovation performance. Therefore, the first hypothesis proposed is as follows:

H1: Entrepreneurial Orientation has significant effect on the innovation performance. In addition, a study conducted by Prajogo and Ahmed (2006) showed that integration between leadership and human resources as well as technology in organizational characteristics will affect the performance of innovation using innovation stimulus modeling. Moreover, some empirical studies show that the character of the bussinesses internal strategy which are part of technology significantly affects innovation performance (Katila, 2002 and Katila and Ahuja, 2002). On this basis, the second hypothesis proposed is:

H2: Organizational characteristics have significant effect on innovation performance. Moreover, Prajogo and Sohal (2001) found that the business environment, organizational strategy and organizational culture have an impact on the practice of total quality management, which determines the quality or performance of innovation. Results of research conducted by Frishamman and Horte (2005) showed a positive effect of the environment on the performance of innovation using multiple regression analysis. The results of research of Hung (2007) also indicate that there is a significant effect of environmental characteristics and the performance of innovation. Therefore, the third hypothesis proposed is:

H3: Environmental characteristics have significant effect on innovation performance.

\section{METHODS OF RESEARCH}

This exploratory study used quantitative research paradigms. The sample of this study consisted of 102 leaders of high-tech SMEs in East Java Province, Indonesia. This research is a one-shot study where the data was collected in a single period of time.

This study used survey method with questionnaire as instrument. Data analysis method used to prove the hypothesis proposed in this study was Generalized Structured Component Analysis (CGCA). Assumptions test in this study used First Order Analysis which covered Outer Model, Inner Model, Overall Model using second order analysis model.

The independent variables in this study consisted of organizational characteristics (X1) which was measured by data base management system, collaborative system, corporate culture collaboration and management participation, as in Li (2002) and the variable of environment characteristics (X2) which was measured by environmental uncertainty, competitive pressures, business college alacrity (Li, 2002) and the entrepreneurial orientation variable (X3) which was measured by innovation, activeness and risk taking, as suggested by Salehi et al (2013); Riche and Agca (2012). Although the dependent variable in this study is Innovation Performance $(\mathrm{Y})$ which was measured using the innovation performance of the product, innovation performance of the market, innovation performance of the process, Innovation performance of the behavior and innovation performance of the strategy. 


\section{RESULTS OF RESEARCH}

The results of evaluation on the outer model of organizational Characteristics (X1) Environmental Characteristics (X2), Entrepreneurial Orientation (X3) and Innovation Performance $(Y)$ showed that all criteria used have a good value, which make it possible to carry out further tests. This is indicated by the value of the convergent validity with the loading parameter factor greater than $\geq 0.500$, discriminant validity with AVE parameters around 0-1 and composite reliability with the Cronbach's alpha parameter $\geq 0.500$

In addition, the evaluation of the structural model of latent constructions (internal model) was conducted to predict the causal relationship between the latent constructs in the model. Table 1 presents the results of the evaluation of the structural model of all variables in this study which shows good value.

Table 1 - Evaluation of the Research Structural Model

\begin{tabular}{|c|c|c|c|}
\hline Parameter & Inner Model Results & Rule of Thumb & Description \\
\hline FIT & 0.732 & $0-1$ & Good \\
\hline AFIT & 0.724 & $\geq 0.500$ & Good \\
\hline
\end{tabular}

The result of evaluation of the overall model is used to indicate that the construct items are significant to substantially form thee five constructs have been studied. Table 2 shows the results of the evaluation of the overall model in this study which shows good value.

Table 2 - Evaluation of the Research Overall Model

\begin{tabular}{|c|c|c|c|}
\hline Parameter & Overall Model Results & Rule of Thumb & Description \\
\hline SRMR & 0.236 & Almost 0 & Good \\
\hline GFI & 0.937 & $\geq 0.500$ & Good \\
\hline
\end{tabular}

Hypothesis tests were performed by comparing the value of $t$ - statistics with the t-table value. If the value of the t-statistic is greater than t-table then between-constructs relationship is significant and can be analyzed further. Table 3 presents the results of the hypothesis tests using iterative bootstrapping in CGCA software in which the three hypothesis tested by the researcher are received. This shows that there is a positive and significant partial impact of high-touch elements, namely entrepreneurial orientation, organizational characteristics and environmental characteristics on high-tech SMEs Innovation Performance.

Table 3 - Hypothesis Test Results

\begin{tabular}{|l|l|l|l|l|l|}
\hline $\mathrm{H}$ & Effect & Coefficient Strip & CR/t-statistic & Description & Results \\
\hline 1 & $\mathrm{X} 1 \rightarrow \mathrm{Y}$ & 0.388 & $6.38^{*}$ & Significant $(+)$ & Accepted \\
\hline 2 & $\mathrm{X} 2 \rightarrow \mathrm{Y}$ & 0.453 & $7.62^{*}$ & Significant $(+)$ & Accepted \\
\hline 3 & $\mathrm{X} 3 \rightarrow \mathrm{Y}$ & 0.356 & $7.45^{\star}$ & Signifikant $(+)$ & Accepted \\
\hline
\end{tabular}

\section{DISCUSSION OF RESULTS}

Based on the results of the hypothesis tests, it was found that entrepreneurial orientation significantly affects the performance. This could be due to the results of this study, in general, high-tech SMEs have sought to innovate, take risks and are proactive in the competitive industry which is a form of entrepreneurial orientation of companies. Therefore, companies tend to support any form of entrepreneurial activity in which it will ultimately improve the performance of innovation within the company. The relationship between entrepreneurial orientation and innovation performance is positive in which it indicates that more the practice processes and entrepreneurial orientation activities in the company, the higher the performance of innovation of the company. The results of hypothesis tests support the idea of Lumpkin and Dess (2011) as well as the research results of Madhoushi (2011) which states that entrepreneurial orientation has a significant effect on the performance of innovation. 
The results of the hypothesis tests showed that the organizational characteristics significantly influence the performance of innovation. The results of this study indicate that the organization characteristics of high-tech SMEs have been effective where the communication support system, database management system, collaborative system, collaborative organizational culture and management participation have been well organized so that that the organizational characteristics of high tech SMEs are able to create innovation performance. The direction of relationship of organizational characteristics and innovation performance is positive in which it indicates that the increasing pressures of the company's organizational characteristics will improve the performance of the company's innovation. The results confirm the results of research conducted by Prajogo and Ahmed (2006) Katila (2002) and Katila and Ahuja (2002) who found that there is an effect of organizational characteristics to performance innovation.

Based on the results of this study, it is also revealed that the environmental characteristics significantly influence the performance of innovation. It may be because hightech SMEs are able to cope with the uncertainty of the environment in terms of understanding consumer tastes, quite high pressure of competitiveness in the industry and necessary business partners vigilance. With the environmental characteristics of high-tech SMEs, the company has a high pressure in generating innovation performance. The relationship betwenn the environmental characteristics and the innovation performance is positive. This indicates that an increasing number of external influences in shaping the environmental characteristics of high-tech SMEs will strengthen the company's capacity in terms of innovation performance. The results support the hypothesis test results of the research conducted by Frishamman and Horte (2005) and Hung (2007) that there is a significant influence between environmental characteristics and the performance of innovation.

\section{CONCLUSION AND RECOMMENDATIONS}

In general, the results of this study indicate that the advancement and sophistication of technology (high tech) must be weighed against human values and have high touch within individual, organization and the environment. The reconciliation between high-tech and hightouch aspects of SMEs is important in shaping the competitive and sustainable innovation performance.

Before yielding and depending all over the internet and technology, companies especially SMEs need to thoroughly examine aspects that require human touch (high touch) and elements that require technology (high tech). Internet and advanced technology cannot strongly and deeply build relationships with people, but the SMEs owners can. On the other hand, people cannot get information and rapidly develop smart products but internet and technology can. Thus, SMEs must learn to use the two together.

Further research can continue investigating the reconciliation of high-tech and hightouch by analyzing important aspects in improving other SMEs innovation performance such as high confidence, high value, high growth and high teach.

\section{REFERENCES}

1. Anderson, Elizabeth. (1995), «High tech v. high touch: a case study of TQM implementation in higher education», Managing Service Quality: An International Journal, Vol. 5 Iss: 2, pp.48 - 56

2. Angehr, Albert A. (1998), «Towards the high-tech, high-touch website», Financial Times, pp. 281-291

3. Bappenas, BPS, UNDP (2001), «Laporan Pembangunan Manusia Indonesia 2001, Menuju Konsensus Baru Demokrasi dan pembangunan Manusia Di Indonesia», Bappenas, BPS, UNDP. Jakarta 
4. Berisha-Shaqiri, Afërdita (2015) «Impact of Information Technology and Internet in Businesses», Academic Journal of Business, Administration, Law and Social Sciences Vol 1 No 1, pp. 73-79

5. Covin, J. P. and Lumpkin, G. T. (2011) «Entrepreneurial Orientation Theory and Research: Reflections on a Needed Construct». EntrpreneurshipTheory and Practice. 35 (5), 855-872

6. Ferrell, Linda and Ferrell, O.C (2012), «Redirecting direct selling: High-touch embraces high-tech», Special Issue: Strategic Marketing In A Changing World, Volume 55, Issue 3, pp. 273-281

7. Frishamman $\mathrm{J}$ and Horte S.A (2005), «Managing external information in manufacturing firms: the impact of innovation performance», The Journal of Product Innovation Management 22 (3) pp. 251-266

8. Grønhaug, K and Möller, K. (2005), «High-tech. Marketing: Fact or Fiction?», Finnish Journal of Business Economics, No. 1, pp. 91-104

9. Gunawan, Theresia. (2015), «The determinants of innovative performance : a study of SMEs in a developing country», Eindhoven: Technische Universiteit Eindhove

10. Halim, Hasliza Abdul, Noor Hazlina Ahmad, T. Ramayah and Haniruzila Hanifah (2014), "The Growth of Innovative Performance among SMEs: Leveraging on Organisational Culture and Innovative Human Capital», Journal of Small Business and Entrepreneurship Development, Vol. 2, No. 1, pp. 107-125

11. Hung, Min (2007), «Influence of the environment on innovation performance of TQM», Total Quality Managment, 18 (7), pp. 715-730

12. Katila R (2002), «New product search over time: past ideas in their prime?» Academy of Management Journal 45 (5) pp. 995-1010

13. Katila R. and Ahuja G (2002), «something old, something new: a longitudinal study of search behaviour and new product intriduction», Academy of Management Journal, 45 (8) pp. 1183-1194

14. Li, Suhong (2002), «An Integrated model for supply chain management practice, performance and competitive advantage», doctoral dissertation. Toledo, $\mathrm{OH}$ : University of Toledo

15. Liu, M.B. (2016), «A Study of the Market Failure in the Financing of High-Tech SMEs and the Governmental Intervention». Open Journal of Social Sciences, 4, 163-169

16. Lumpkin , G. T. and Gregory G. Dess (1996), «Clarifying The Entrepreneurial Orientation Construct And Linking It To Performance», Academy Of Management Review, Vol. 21, No. 1, 135-172., Academy Of Management Review, Pp. 135-172

17. Madakam, S., Ramaswamy, R. and Tripathi, S. (2015), «Internet of Things (loT): Literature Review». Journal of Computer and Communications, 3, 164-173.

18. Madhoushi, Mehrdad, Abdolrahim Sadati, Hamidreza Delavari,Mohsen Mehdivand and Ramin Mihandost. (2011), «Entrepreneurial Orientation and Innovation Performance: The Mediating Role of Knowledge Management», Asian Journal of Business Management, 3(4): 310-316

19. Moreno, A. M., Casillas, J. C., (2008), «Entrepreneurial orientation and growth of SMEs: A causal model», Entrepreneurship Theory and Practice, 32, 507-528

20. Mura, Ladislav and Rózsa, Zoltán. (2013). «The Impact Of Networking On The Innovation Performance Of SMEs», The $7^{\text {th }}$ International Days of Statistics and Economics, Prague, pp.1036-1041

21. Ndesaulwa, Audrey Paul, «The Impact of Innovation on Performance of Small and Medium Enterprises (SMEs) in Tanzania: A Review of Empirical Evidence.» Journal of Business and Management Sciences, vol. 4, no. 1, pp. 1-6.

22. Okorie N. N, Kwa D.Y, Olusunle S.O.O., Akinyanmi A.O, Momoh I.M. (2014), «Technopreneurship: An Urgent Need In The Material World For Sustainability In Nigeria», European Scientific Journal vol.10, No.30

23. Palma, Daniel, Juan Enrique Agudo, Héctor Sánchez and Miguel Macías Macías (2014), «An Internet of Things Example: Classrooms Access Control over Near Field Communication», Sensors, 14, pp. 6998-7012 
24. Prajogo D.I and Ahmed P.K (2006), «Relationship between innovation stimulus, innovation capacity, and innovation performance», R\&D management, 36 (5) pp.499-515

25. Prajogo D.I and Sohal A.S (2001) «The relationship between TQM practices, quality performance and innovation performance», International Journal Of Quality And Relaibility Management, 20 (8) pp. 901-918

26. Raiwan, Y.P. (2013), «Internet of Things: A New Paradigm», International Journal of Scientific and Research Publications, Volume 3, Issue 4

27. Rehman, Naqeeb Ur. (2016), «Innovation Performance of Chilean SMEs: A Bivariate Probit Analysis», MPRA Munich Personal RePEc Archive

28. Reuber, Rebecca and Fischer, Eileen. (2011), «International entrepreneurship in internetenabled markets», Journal of Business Venturing, Volume 26, Issue 6, pp. 660-679

29. Rosen, Lawrence D. (2011), «High-Tech, High-Touch: Reconciling Technology and Integrative Medicine», EXPLORE, Vol. 7, No. 3 138-140

30. Saad, M.S.M. and Mazzarol, T. (2010), «The Impact of Leadership on Organisational Innovation Performance among Malaysia's Multimedia Super Corridor (MSC) SMEs», International Conference on Applied Business Research (ICABR)

31. Samani, Afshan, Hamada H.Ghenniwa, Abdulmutalib Wahaish. (2015), «Privacy in Internet of Things: A Model and Protection Framework», Procedia Computer Science 52, pp. $606-613$

32. Seroka-Stolka, Oksana and Piotr Tomski. (2015), «Internet Social Media And International Entrepreneurial Intentions», WEI International Academic Conference Proceedings Vienna, Austria 